\title{
Leadership through Innovation and Creativity in Marketing Strategies of Indian Telecom Sector: A Case Study of Airtel Using Factor Analysis Approach
}

\author{
Dr. Harsh Dwivedi \\ Director, R.A Podar Institute of Management \\ University of Rajasthan, \\ J. L.N Marg, Jaipur Rajasthan, India \\ E-mail: harsh_dwivedi1@rediffmail.com \\ Leena Sharma (Corresponding author) \\ Research scholar, R.A Podar Institute of Management \\ Assistant Professor, Suresh Gyan Vihar University \\ R.A Podar Institute of Management, FMS, University of Rajasthan \\ Suresh Gyan Vihar University, Mahal Jagatpura, Jaipur, Rajasthan, India \\ 4 Shahar house, Civil Lines, Ajmer Road, Jaipur, Rajasthan \\ Tel: +91-982-999-1000Ｅ-mail: leenasharma5@rediffmail.com
}

Received: September 4, 2011

doi:10.5430/ijba.v2n4p122
Accepted: October 3, 2011 Published: November 21, 2011

URL: http://dx.doi.org/10.5430/ ijba.v2n4p122

\begin{abstract}
The telecom sector have been touched and influenced by the process of liberalization and globalization in India. The customer is the king in the market. Telecom companies deal in intangible product that is the call service. With the entry of private players, the competition is becoming intense. In order to satisfy the customer, every company is trying to implement a program of marketing strategy. Keeping this in mind, the present study is designed to analyze the marketing strategy in Indian Telecommunication sector. This study aims to identify the factors responsible for success in terms of getting a market leader position .Brand Airtel is chosen as a case study as it has emerged as a market leader within a short span of time in spite of so many mobile companies prevailing in the market. The study describes the result of survey done with respondents which are the present subscribers of Airtel. The result and analysis is done by using the Factor Analysis tool. The study concludes that out of thirty two marketing strategies, eleven factors are extracted which are found to be more prominent in implementing the marketing strategy. The Company’s marketing strategies are studied and out of which prominent strategies like branding strategy, business operation strategy, target marketing strategy, Service strategy, Network, promotion and pricing strategy are identified. In the end, with the help of results, how successful is the company in implementing the blue ocean strategy is also analyzed.
\end{abstract}

Keywords: Marketing Strategy, Pricing, Promotion, Branding, Services, Blue Ocean Strategy, Telecom Service Provider

\section{Introduction}

Nowadays telecommunication is a fascinating fast-growing industry that affects each and every aspect of our lives including simple voice telephone calls, access to the Internet, high speed data communications, satellite communications, surfing the World Wide Web, fax transmissions, video conferencing and cable television. The industry is witnessing exceptional growth rates and amidst growing competition it would be tough for mobile operators to survive, unless they strengthen there marketing strategies. Mobile phone market in India has been healthy in the recent years. The Indian Telecom market is likely to see changes in the sphere of marketing strategies. The customer-driven market would result in many flexibilities and innovations in products, pricing, distribution channels and communication mechanisms. The 
Telecom Regulatory authority of India (TRAI), with its developmental and regulatory guidelines, is likely to endorse competition, fairness and reliability, and at the same time protect the customer against excessive, inadequate or unfairly discriminatory rates, while efforts at intensifying the existing distribution channels and making them more effective would continue. The market is expected to continue growing, hence current operators are expanding the network through out the country. There are also some new operators entering the market soon. Since then the market would be more competitive. The introduction of new intermediaries and utilization of electronics media and Internet would call for new marketing strategies. Communication to create more awareness and greater demand for value added services would continue to assume high importance. At the same time, unfair or misleading advertisements would be discouraged and necessary checks and controls be put in place.

Thus only experimenting on 4 P's of marketing won't go for the mobile company as there is need to focus on managing the marketing strategies covering services efficiency, network connectivity, after sales services, more value added services, while managing the operation side of business by outsourcing. The present paper focuses on current marketing strategies of telecom sector in India's with special reference of market leader "AIRTEL”, it also answer that how effectively this brand has managed with its marketing strategies by getting the likelihood level of its current subscribers.

\section{Objectives of the Study}

To identify the prominent marketing strategies factors influencing the growth of Airtel in Rajasthan circle and responsible for the company's market leader position from the response of the Airtel Subscribers towards each of the factor of marketing strategy.

\section{Research Methodology}

\subsection{Scope of the Study}

The scope of the study is limited to the survey of current subscribers of Airtel from selected city Jaipur. City is selected as a base for research as it has got the highest number of subscribers of Airtel in Rajasthan.

\subsection{Sample Size and Nature of Respondents}

The effective sample size for this research study is 400 . Although 430 respondents have responded, 30 of them were rejected on account of errors and other issues related to the insufficiency of data. Respondents are drawn on convenient sample method. Age of the respondents were differed under three categories 18-25, 25-40 and 40 and above. The respondents differed in terms of four types of employment such as Government based, Private Based, Business (Self Employed), student and any other category. The respondents also differed in terms of educational qualifications like Doctoral Degree (Ph.D.), Post Graduate, Graduate, Secondary School and Below Secondary. Both male and female respondents are considered for this study. The frequency distributions of various groups of respondents are displayed as Table 1(Appendix).

\subsection{Data Collection Source}

Research data was collected from both primary and secondary sources. The primary data was collected by administering questionnaire to the respondents. Questionnaires were administered to them by meeting them in their respective offices with prior appointment Secondary data sources were also used to collect the data for this research study. Convenience sampling is done to collect the data.

\subsection{Research Method Tool}

A Questionnaire of 32 factors (variables) was developed to measure the attitudes of the respondents. A research framework was constructed to extract the relevant factors affecting the marketing strategies. In line with the proposed research design, eigenvalue of more than 1 was identified and the relevant factors have been obtained accordingly by linking them to the corresponding statements in the questionnaire. Responses are taken on 5 point likert scale from 1 being strongly agree to 5 being strongly disagree.

Analysis of the data collected is done through SPSS version 18.Factor analysis tool is used to get the desired results. Analysis of the results indicated that a total of $82.577 \%$ the variance (information from the 32 factors) was observed. Eleven factors were derived from this study.

\subsection{Factor Analysis Method}

Questionnaires were collected from a sample of 400 respondents after ensuring that there were no errors while they completed the questionnaire. The data was entered into SPSS data sheet. Reliability test was performed and the data was subjected to further analysis by using Principal Components Analysis (PCA) method. Varimax rotation with Kaiser Normalization was chosen to get the \% of variance for 32 statements in the questionnaire. Eigenvalue of greater than 1 
was identified and the relevant factors have been obtained accordingly in line with the statements in the questionnaire. The list of factors along with the supporting statements is displayed in Table 2 (appendix).

\section{Study Analysis}

From principle component analysis the factor loading of the variable of the strategy of the Airtel has been identified , eight prominent factors : Branding strategy, outsourcing strategy, targeting market strategy, Vas Strategy, distribution strategy, promotion , pricing and after sales service strategy.

The growth in subscribers and company's success are influenced by these factors. The present study identified the most important factors influencing consumers to purchase Airtel mobile through factor Analysis. Kaiser-Meyer-Olkin Measure of sampling adequacy was .653 proving the efficiency of the test (Table 3).

\subsection{Description of Components}

Component 1 is of Branding strategy and that component 1 comprises of $23.228 \%$ of variance. This factor is descried in terms of indian brand, with factor score of .682, although reliability of brand also contributes more to this factor.

Component 2 refers to Network /Distribution strategy used by the company and comprises of $10.943 \%$ of variance. Third factor is described in terms of Roaming Facility, with factor score of .641.

Component 3 refers to the after sales service strategy used by the company by dealing with the customer care service well to cater to the complaints, and queries of the customers well. This factor contributes to $9.102 \%$ of variance which after rotation attains the score of 8.075 .

Component 4 and 5, focuses on the outsourcing strategy adopted by the company to make its business operation successful, and to ease it focus on the marketing side and contributes to $7.343 \%$, and $6.407 \%$ of variance respectively. This factor includes outsourcing the IT to IBM, and outsourcing the network to Ericsson and Nokia.

Component 6, contributes to the Pricing strategy of Airtel .The customized plan offered by the company in Rajasthan help to make the pricing strategy successful. Special 5 plan is the part of this strategy.

Component 7, contributes to the brand image with variance $4.95 \%$.

Component 8, contributes to the VAS strategy adopted by innovative SMS scheme launched contributes to variance $4.423 \%$.

Component 9 and 10 contributes to service quality, proactive and innovative service variance is $3.583 \%$

Component 11 depict the effect of Promotion strategy of Airtel by taking A R Rahman ring tone composition and taking celebrities for advertising there brand.

From the scree Plot obtained from factor analysis, it is observed that component 1 and 2 are on the more steep slope thus contributes more to the factor extraction and till component 11 the slope is still somewhat sleep but after that slope is shallow and thus remaining components contributes little to the solution .(As shown in Graph 1).

The Extraction matrix using the principle component analysis depict the the variance of extracted loading and rotated sum loading enclosed in table 4). The component matrix (Table 5) and rotated component matrix( Table 6) further proves the loading and variance of the factors.

The response of the respondents towards each of the factors of marketing strategy (enclosed as Table 7).From the research findings, it is clear that $74 \%$ of the respondents strongly agree that Airtel is chosen as there service provider because of the brand image, 50\% agree to the fact that Indian brand is favored as compare to the competitors brand .The status symbol, reliability and leadership of the brand get the favorable \% of strongly agreeableness, $36 \%$, $54 \%$ and $58 \%$ respectively. Thus it can be concluded that Airtel is being successful in implementing the branding strategy .Company's outsourcing strategies are also well recognized by the customers, which is helping the company to smoothen its operations of network and data servers. As evidence $52 \%$ of the respondents agree to the voice clearance, $56 \%$ strongly agree to the network connectivity, $60 \%$ strongly agree to the ease of availability and recharge facility, and $64 \%$ in network coverage. Although $40 \%$ and $34 \%$ respondents were not aware about the outsourcing partners of the company.70 \% of the customers agree that Airtel is always first in implementing any new market moves.

\section{Discussion}

\subsection{Implementing the Blue Ocean Strategy: The Airtel Way}

By creating uncontested market space, Airtel has gained the position of market leader by its strategy of value innovation by focusing on new Value Added services like innovative SMS Pack scheme. The value added services are designed to cater to the need of technologically advanced youth segment. Also the professional and elite class customer find the 
value services convenient like Airtel Live and Mobile Office. Also where too many telecom companies like Vodafone, DoCoMo, MTS, Aircel, Reliance and BSNL are swimming in red Ocean of bloody competition, Airtel has gained the first mover advantage in implementing its strategy of pricing both defined for pre and post paid customers. Another proof of implementing the blue ocean strategy is the strategy of outsourcing the business core operations that is IT, servers and network to the Global companies like IBM, Ericsson and Nokia so that company can focus on customer side thereby getting differentiation and low cost.

\subsection{Branding Strategy}

Brand increase the value of products and services by differentiating them from the competition, creating positive mental associations and forming emotional relationships with the customer (Agarwal, 2010) .This is really catered well by AIRTEL as a brand. The core values of the brand were leadership, performance, enthusiasm and dynamism forms the integral part of its branding strategy. Further, Airtel is a product of Bharti Enterprises which is visualized by the customers as Reliable Indian Brand. Dominant in the telecommunications services market, Bharti Enterprises, the telecom giant has unveiled its vision for 2020. Its brand status symbol attempts to reflect its intent to grow its other businesses such as financial services, retail and agri-business.

\subsection{Business Outsourcing Strategy}

Airtel as part of its outsourcing strategy is enjoying unparalleled competitive advantages by way of lower costs, improved quality and responsiveness. This is done by outsourcing the IT to IBM and network to Nokia/Ericsson. Apart from it the social initiatives made time to time by the company is really recognized and praised by the customer.

\subsection{Market Segmentation Strategy}

Because of its leadership position in Rajasthan Circle, the company is always ready to take the first mover advantage before the competition. All the new plan, schemes and services are first initiated by Airtel.As part of its market segmentation strategy Airtel focuses on concentrating on elite, professional and small entrepreneurs which make its brand identity as lifestyle and aspirational brand. But because of more disposable income of the youth segment the target market is also the technology driven and demanding youth market.

\subsection{Value Added Services Strategy}

Although the Airtel Vas market in Rajasthan is only $15 \%$ of the revenue, but still it is the highest in the circle. The maximum contribution goes to the Sms pack schemes, then Airtel Live portal and mobile office.

\subsection{Distribution /Network Strategy}

The efficiency of a telecom service provider is judged by its network. The roaming facilities, network coverage, ease of availability of recharge outlets, voice clearance contributes to the success of Airtel as a Leader.

\subsection{Promotion Strategy-Creative Advertising Campaign}

Made by the company by taking the famous celebrities as brand ambassadors and taking Ringtone composed by A.R Rahman as a promotion tool made it easy to get the word of mouth publicity.

\subsection{Pricing Strategy}

The best 5 plan offered by the company to Rajasthan circle especially to the postpaid customer is the best strategy to increase the number of subscribers. The plan includes: Airtel Freedom 249, Advantage 199, Easy plan 149, Super Combo plan, STD benefit plan. In addition to it the consideration of rebates and discount on calls also add to the effectiveness of pricing strategy.

\subsection{After Sales Service Strategy}

Airtel is getting a satisfactory report on the customer care services and the dealer services are also managed well .Airtel is very particular in proving Transparency in Billing to the customer. Thus well focused after sales service helps the company to retain its customer in spite of starting of mobile number portability (MNP).

\section{Conclusion}

The findings of this research study revealed that success of telecom service Provider Company depend upon the effective implementation of its marketing strategy. This research study demonstrates that out of all thirty two statements that describe Airtel's marketing strategy only 11 statements describes best the factors of marketing strategy. These statements are brand image, outsourcing IT and network, concentrate on youth segment, SMS packs, network and roaming facility, Promotion through Rahman's ring tone and celebrities advertisements, special 5 plans innovative schemes and offers and customer care services. Research also concludes that apart from 4 P's of marketing strategy 
(product, price, place and promotion) ,business operation strategy of outsourcing and after sales service strategy adopted by the company also plays a very important role.

\section{References}

Agarwal, H. V. (2010). Cool Customers Hot Br\&s.4Ps Business \& Marketing. Vol-V Issue 18.pp124-125.

Ammani, P. (2009). Advertising Decision Making Process. The Icfaian Journal of Management Research. Vol -VIII. No 6.pp 60-76.

Beri, G.C. (2007). Business Statistics( $2^{\text {nd }}$ ed.). Tata McGraw-Hill. Chapter 5. pp72-104.

Blackwell, M.E. (2006).ConsumerBehavior(10 $0^{\text {th }}$ ed.). Thomson Publications.Chapter10.pp330-374

Caruana, A. (2004). The impact of switching costs on customer loyalty: A study among corporate customers of mobile telephony . Journal of Targeting. Measurement \& Analysis for Marketing .Vol. 12. No. 3. pp. 256 - 268 . http://dx.doi.org/10.1057/palgrave.jt.5740113

David L.L., Albert.J. \& Della, B. (2004). Consumer Behavior (4th ed.) . Tata McGraw-Hill. Chapter 6.pp214-246

Denison, T. \& McDonald. M. (1995). The role of marketing past. present \& future. Journal of Marketing Practice: Applied Marketing Science.Vol 1. Issue 1. pp 54-56. http://dx.doi.org/10.1108/EUM0000000003880

Evans, M. (2002) Prevention is better than cure: Redoubling the focus on customer retention .Journal of Financial Services Marketing. Vol.7. No.2 .pp.186 - 198. http://dx.doi.org/10.1057/palgrave.fsm.4770083

Grant, M. (1999). The Journal of Consumer Research. Vol. 16. No. 3. pp. 310-321

Heejin, L., Richard, W. \& Jungkun, P. (2006). M-loyalty: Winning strategies for mobile carriers .Journal of Consumer Marketing . Vol. 23. No. 4 .pp. 208 - 218. http://dx.doi.org/10.1108/07363760610674338

Kotler, P. \& Armstrong, G. (2004). Principles of Marketing (10th ed).New Delhi: Pearson..(Chapter 4)

Kim, J. \& Mueller, C. W. (1978). Factor Analysis: What It Is \& How To Do It. Beverly Hills \& London: Sage Publications.

Kim, J. \& Mueller, C. W. (1978). Factor Analysis: Statistical Methods \& Practical Issues. Beverly Hills \& London: Sage Publications.

Malik, V. (2010). The New Marketing Border . The Journal of AIMA.Vol 49.issue 10.pp82-84.

Rahman, Z. (2006). Superior Service Quality in Indian Cellular Telecommunication Industry.Services Marketing Quarterly. Vol 27. pg 115 - 139.http://dx.10.1300/J396v27n04_07

Saxena, R. (2004). Marketing Management (2nd Ed). New Delhi: Tata McGraw-Hill. (Chapter 13)

Xevelonakis, E. (2005). Developing retention strategies based on customer profitability in telecommunications: An empirical study .The Journal of Database -Marketing \& Customer Strategy Management. Vol. 12 No. 3. pp. 226 242 . http://dx.doi.org/10.1057/palgrave.dbm.3240259

Web source: http://www.airtel.in/ 
Table 1. Frequency distribution of the respondents

\begin{tabular}{|c|c|c|c|c|}
\hline \multicolumn{2}{|c|}{} & Frequency & Percent & Cumulative Percent \\
\hline \multirow{4}{*}{ Age } & $18-25$ & 136 & 34.0 & 34.0 \\
\cline { 2 - 5 } & $25-40$ & 136 & 34.0 & 68.0 \\
\cline { 2 - 5 } & 40 and above & 128 & 32.0 & 100.0 \\
\cline { 2 - 5 } & Total & 400 & 100.0 & \\
\hline Occupation & Govt employed & 112 & 14.0 & 14.0 \\
\cline { 2 - 5 } & Private emp & 192 & 24.0 & 38.0 \\
\cline { 2 - 5 } & Professional & 160 & 20.0 & 58.0 \\
\cline { 2 - 5 } & Self employed & 176 & 22.0 & 80.0 \\
\cline { 2 - 5 } & Student & 160 & 20.0 & 100.0 \\
\cline { 2 - 5 } & Total & 200 & 100.0 & \\
\hline Gender & Male & 308 & 77.0 & 77.0 \\
\cline { 2 - 5 } & Female & 92 & 23.0 & 100.0 \\
\cline { 2 - 5 } & Total & 400 & 100.0 & \\
\hline Education & Bachelor degree & 112 & 28.0 & 28.0 \\
\cline { 2 - 5 } & Post graduate & 244 & 61.0 & 89.0 \\
\cline { 2 - 5 } & Sr. Secondary & 12 & 3.0 & 92.0 \\
\cline { 2 - 5 } & PhD & 28 & 7.0 & 99.0 \\
\cline { 2 - 5 } & Metric & 4 & 1.0 & 100.0 \\
\cline { 2 - 5 } & Total & 400 & 100.0 & \\
\cline { 2 - 5 } & & & & \\
\hline
\end{tabular}

Table 2. Factor loading from principle component analysis

\begin{tabular}{|c|c|c|}
\hline Item & Marketing Variables & Loading \\
\hline 1 & Brand Image & .882 \\
\hline 2 & Indian Brand & .777 \\
\hline 3 & Market leader & .751 \\
\hline 4 & Reliable brand & .812 \\
\hline 5 & Status Symbol & .776 \\
\hline 6 & Outsourcing to Ericcson and Nokia for network & .808 \\
\hline 7 & Outsourcing IBM to IT & .846 \\
\hline 8 & Social initiatives by the Company & .832 \\
\hline 9 & First Mover Advantage & .701 \\
\hline 10 & Concentrate on elite,professional ,entrepreneurs & .753 \\
\hline 11 & Concentrate on the youth segment & .825 \\
\hline 12 & Airtel Live & .729 \\
\hline 13 & Mobile offices & .854 \\
\hline 14 & Innovative SMS pack schemes & .779 \\
\hline 15 & Network connectivity & .776 \\
\hline 16 & Voice clearance & .871 \\
\hline 17 & Eroactive and innovative service & .828 \\
\hline 18 & & .875 \\
\hline 19 & Network coverage & .865 \\
\hline 20 & Roaming facility & .871 \\
\hline 21 & Service quality & .833 \\
\hline
\end{tabular}




\begin{tabular}{|c|c|c|}
\hline 22 & Advertisemnt by celebrities & .906 \\
\hline 23 & A R Rahman Ringtone & .925 \\
\hline 24 & Creative advertising campaigns & .816 \\
\hline 25 & Word of Mouth Publicity & .779 \\
\hline 26 & Various innovative schemes and offers & .802 \\
\hline 27 & Consideration on rebates and discount on calls & .915 \\
\hline 28 & Call tariff plans & .810 \\
\hline 29 & Newly introduced special 5 Plan & .785 \\
\hline 30 & Transparency in Billing & .832 \\
\hline 31 & Dealer services & .848 \\
\hline 32 & Customer care services & .900 \\
\hline
\end{tabular}

Table 3. Sample adequacy test

\begin{tabular}{|c|c|c|}
\hline Kaiser-Meyer-Olkin Measure of Sampling Adequacy. & .653 \\
\hline Bartlett's Test of Sphericity & Approx. Chi-Square & 3182.822 \\
\cline { 2 - 3 } & Df & 66 \\
\cline { 2 - 3 } & Sig. & .000 \\
\hline
\end{tabular}

Table 4: Extraction method-Principal component analysis.

\begin{tabular}{|c|c|c|c|c|c|c|c|c|c|c|}
\hline & & & & & Total Va & riance Expl & ained & & & \\
\hline Com & nponent & & nitial Eigenv & alues & Extr & $\begin{array}{r}\text { Iction Sums } \\
\text { Loadin }\end{array}$ & $\begin{array}{l}\text { of Squared } \\
\text { gs }\end{array}$ & Rotation S & ums of Squa & red Loadings \\
\hline & & Total & $\begin{array}{c}\text { \% of } \\
\text { Variance }\end{array}$ & $\begin{array}{c}\text { Cumulative } \\
\%\end{array}$ & Total & $\begin{array}{c}\text { \% of } \\
\text { Variance }\end{array}$ & Cumulative \% & Total & $\begin{array}{c}\% \text { of } \\
\text { Variance }\end{array}$ & $\begin{array}{c}\text { Cumulative } \\
\%\end{array}$ \\
\hline & 1 & 7.433 & 23.228 & 23.228 & 7.433 & 23.228 & 23.228 & 3.619 & 11.311 & 11.311 \\
\hline & 2 & 3.502 & 10.943 & 34.171 & 3.502 & 10.943 & 34.171 & 3.427 & 10.709 & 22.020 \\
\hline & 3 & 2.913 & 9.102 & 43.273 & 2.913 & 9.102 & 43.273 & 2.584 & 8.075 & 30.094 \\
\hline & 4 & 2.350 & 7.343 & 50.616 & 2.350 & 7.343 & 50.616 & 2.553 & 7.978 & 38.072 \\
\hline & 5 & 2.050 & 6.407 & 57.023 & 2.050 & 6.407 & 57.023 & 2.552 & 7.976 & 46.048 \\
\hline & 6 & 1.718 & 5.368 & 62.391 & 1.718 & 5.368 & 62.391 & 2.322 & 7.257 & 53.305 \\
\hline & 7 & 1.584 & 4.951 & 67.342 & 1.584 & 4.951 & 67.342 & 2.183 & 6.822 & 60.127 \\
\hline.$\frac{0}{n}$ & 8 & 1.415 & 4.423 & 71.765 & 1.415 & 4.423 & 71.765 & 1.859 & 5.809 & 65.936 \\
\hline $\bar{\Xi}$ & & 1.259 & 3.936 & 75.701 & 1.259 & 3.936 & 75.701 & 1.823 & 5.697 & 71.633 \\
\hline a & 10 & 1.147 & 3.583 & 79.284 & 1.147 & 3.583 & 79.284 & 1.790 & 5.595 & 77.228 \\
\hline & 11 & 1.054 & 3.293 & 82.577 & 1.054 & 3.293 & 82.577 & 1.712 & 5.349 & 82.577 \\
\hline & 12 & .842 & 2.631 & 85.207 & & & & & & \\
\hline & 13 & .676 & 2.111 & 87.319 & & & & & & \\
\hline & 14 & .646 & 2.018 & 89.337 & & & & & & \\
\hline & 15 & .542 & 1.695 & 91.032 & & & & & & \\
\hline & 16 & .507 & 1.586 & 92.618 & & & & & & \\
\hline
\end{tabular}




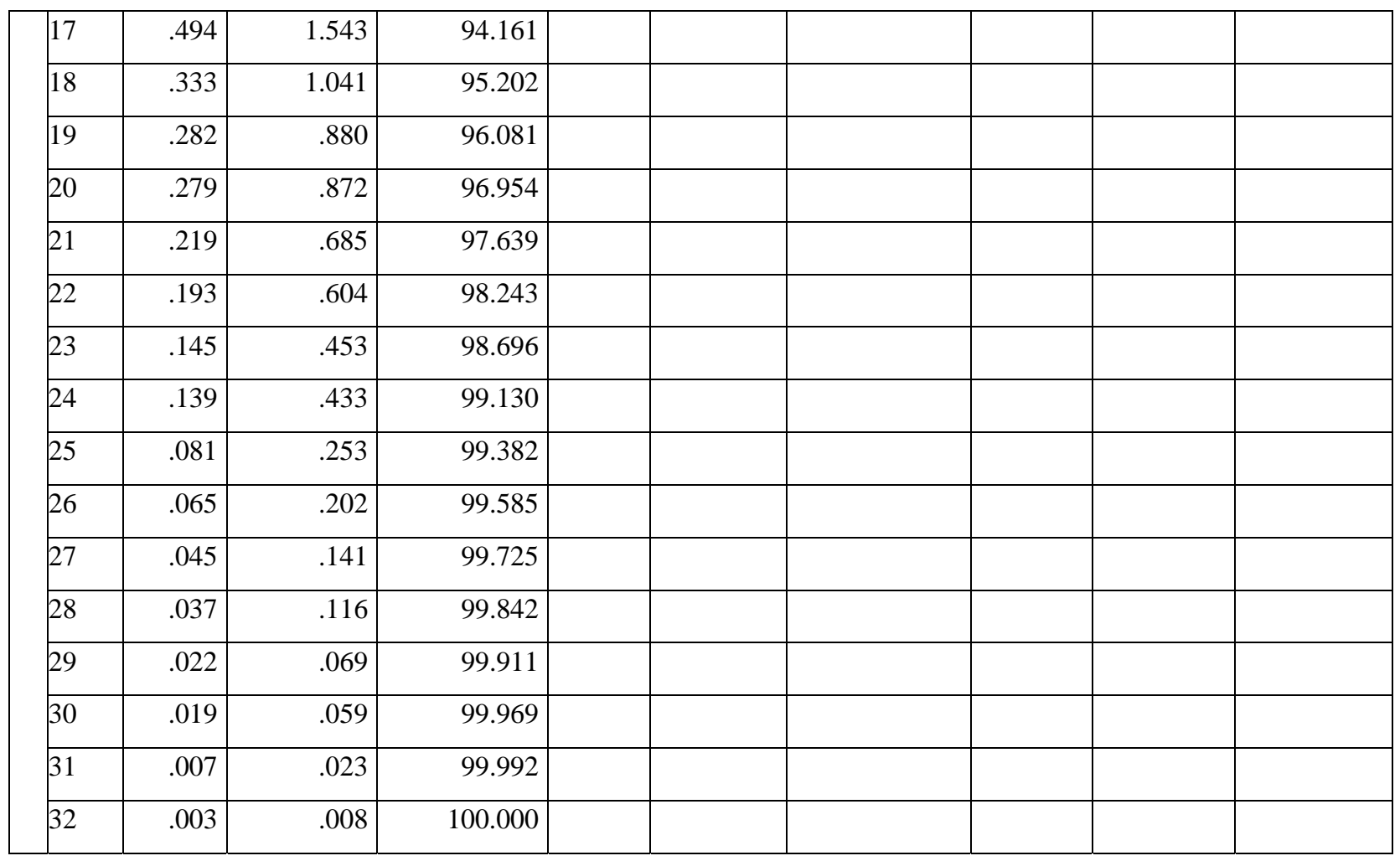

Table 5. Component matrix

\begin{tabular}{|c|c|c|c|c|c|c|c|c|c|c|c|}
\hline & \multicolumn{10}{|c|}{ Component } \\
\cline { 2 - 10 } & 1 & 2 & 3 & 4 & 5 & 6 & 7 & 8 & 9 & 10 & 11 \\
\hline Brand Image & .543 & .186 & -.356 & -.081 & -.330 & -.027 & .449 & .237 & -.124 & .190 & .016 \\
\hline Indian Brand & .682 & -.337 & -.198 & .061 & -.050 & .234 & -.067 & .140 & -.238 & .041 & .128 \\
\hline Market leader & .441 & -.580 & -.072 & .153 & .216 & -.041 & .215 & .059 & -.108 & .110 & .265 \\
\hline Reliable brand & .645 & -.148 & -.441 & -.011 & -.019 & .284 & .054 & -.213 & .102 & .153 & .125 \\
\hline Status Symbol & .591 & -.149 & -.197 & -.064 & -.317 & .239 & .437 & -.096 & -.054 & .036 & .016 \\
\hline $\begin{array}{c}\text { Outsourcing to Ericcson and } \\
\text { Nokia for network }\end{array}$ & .391 & -.261 & .005 & -.226 & .549 & .205 & .070 & .210 & .368 & -.083 & .043 \\
\hline Outsourcing IBM to IT & .070 & -.168 & -.007 & .482 & .232 & .616 & -.177 & .045 & .318 & -.100 & .047 \\
\hline $\begin{array}{c}\text { Social initiatives by the } \\
\text { Company }\end{array}$ & .544 & -.126 & .203 & .358 & .015 & .123 & -.002 & -.008 & .090 & -.029 & -.571 \\
\hline First Mover Advantage & .331 & -.309 & .227 & -.069 & -.529 & -.119 & -.264 & .113 & -.160 & -.194 & -.001 \\
\hline $\begin{array}{c}\text { Concentrate on elite, } \\
\text { professional ,entrepreneurs }\end{array}$ & .474 & .305 & -.077 & .400 & -.012 & .278 & .038 & -.136 & -.360 & .186 & -.087 \\
\hline $\begin{array}{c}\text { Concentrate on the youth } \\
\text { segment }\end{array}$ & .234 & .236 & -.360 & .077 & .462 & -.287 & .202 & -.484 & -.063 & -.045 & -.043 \\
\hline Airtel Live & .546 & -.256 & -.088 & -.348 & .290 & .133 & -.337 & .105 & -.072 & .060 & .032 \\
\hline Mobile offices & .211 & .404 & .360 & .136 & .393 & .012 & .075 & .307 & -.163 & .429 & -.185 \\
\hline $\begin{array}{c}\text { Innovative SMS pack schemes } \\
\text { Network connectivity }\end{array}$ &. .352 & .524 & .231 & -.068 & -.124 & -.180 & -.068 & .376 & .091 & .258 & .233 \\
\hline Voice clearance & .475 & -.089 & -.024 & .404 & .125 & -.225 & -.448 & -.258 & .065 & .353 & .110 \\
\hline $\begin{array}{c}\text { Ease of availability and } \\
\text { recharge facility }\end{array}$ & .336 & .444 & -.332 & .069 & .172 & -.288 & -.172 & .277 & .260 & -.339 & -.049 \\
\hline Network coverage & .643 & .087 & -.376 & -.115 & -.194 & -.043 & -.411 & -.058 & -.235 & -.122 & .134 \\
\hline Roaming facility & .190 & .641 & .242 & .506 & -.063 & -.018 & .061 & .043 & -.075 & -.022 & .296 \\
\hline
\end{tabular}




\begin{tabular}{|c|c|c|c|c|c|c|c|c|c|c|c|}
\hline Service quality & .580 & .193 & -.312 & -.023 & -.343 & .091 & -.121 & -.367 & .343 & -.065 & -.042 \\
\hline $\begin{array}{c}\text { Proactive and innovative } \\
\text { service }\end{array}$ & .440 & .310 & .294 & .450 & .015 & -.085 & .153 & -.167 & .013 & -.370 & .344 \\
\hline Advertisemnt by celebrities & .628 & -.260 & .472 & -.069 & -.067 & -.389 & -.188 & -.044 & -.078 & -.071 & -.111 \\
\hline A R Rahman Ringtone & .674 & -.502 & .253 & .151 & -.028 & -.288 & .063 & .004 & -.089 & -.149 & -.122 \\
\hline $\begin{array}{c}\text { Creative advertising } \\
\text { campaigns }\end{array}$ & .528 & -.454 & .351 & -.057 & .078 & -.206 & .285 & -.203 & .038 & .109 & -.141 \\
\hline Word of Mouth Publicity & .410 & -.083 & .020 & .430 & -.302 & -.244 & .105 & .246 & .435 & .051 & -.068 \\
\hline $\begin{array}{c}\text { Various innovative schemes } \\
\text { and offers }\end{array}$ & .385 & .360 & .376 & -.301 & .254 & -.046 & .331 & -.267 & .045 & -.199 & .050 \\
\hline $\begin{array}{c}\text { Consideration on rebates and } \\
\text { discount on calls }\end{array}$ & .575 & .142 & -.597 & -.039 & -.029 & -.150 & .149 & .323 & .161 & -.025 & -.172 \\
\hline Call tariff plans & .364 & .520 & -.202 & -.255 & .094 & .139 & .036 & .087 & -.304 & -.307 & -.278 \\
\hline $\begin{array}{c}\text { Newly introduced special 5 } \\
\text { Plan }\end{array}$ & .483 & .159 & .433 & .081 & .023 & .444 & -.196 & .107 & -.177 & -.216 & -.090 \\
\hline Transparency in Billing & .640 & -.192 & .259 & -.274 & .286 & .020 & .130 & .216 & -.027 & -.133 & .281 \\
\hline Dealer services & .318 & .157 & .344 & -.611 & -.289 & .181 & -.053 & -.120 & .246 & .143 & .130 \\
\hline Customer care services & .412 & .478 & .474 & -.245 & -.186 & .202 & -.024 & -.199 & .224 & .187 & -.127 \\
\hline
\end{tabular}

Extraction Method: Principal Component Analysis.

11 components extracted.

Table 6. Rotated component matrix

\begin{tabular}{|c|c|c|c|c|c|c|c|c|c|c|c|}
\hline & \multicolumn{11}{|c|}{ Component } \\
\hline & 1 & 2 & 3 & 4 & 5 & 6 & 7 & 8 & 9 & 10 & 11 \\
\hline Brand Image & .036 & .829 & .073 & -.014 & .009 & .073 & .283 & -.256 & -.035 & .176 & .068 \\
\hline Indian Brand & .268 & .562 & -.145 & .384 & .356 & .023 & -.036 & .168 & -.220 & -.013 & .129 \\
\hline Market leader & .364 & .371 & -.341 & .139 & .498 & .037 & -.165 & .044 & .048 & -.005 & -.254 \\
\hline Reliable brand & .041 & .671 & .109 & .401 & .238 & -.045 & .053 & .255 & .179 & -.162 & -.043 \\
\hline Status Symbol & .231 & .810 & .160 & -.041 & .111 & .043 & -.038 & .045 & .018 & -.133 & .063 \\
\hline $\begin{array}{c}\text { Outsourcing to Ericcson and } \\
\text { Nokia for network } \\
\end{array}$ & .106 & .034 & .093 & -.025 & .772 & -.178 & .202 & .301 & .158 & .048 & -.029 \\
\hline Outsourcing IBM to IT & -.119 & -.010 & -.116 & .030 & .188 & .130 & -.031 & .865 & -.076 & -.034 & -.096 \\
\hline Social initiatives by the Company & .641 & .176 & .067 & .027 & -.098 & -.013 & .167 & .521 & .039 & .221 & .159 \\
\hline First Mover Advantage & .485 & .094 & .084 & .172 & -.040 & .042 & -.006 & -.131 & -.571 & -.253 & .095 \\
\hline $\begin{array}{c}\text { Concentrate on elite, } \\
\text { professional ,entrepreneurs }\end{array}$ & .073 & .450 & -.023 & .309 & -.197 & .340 & -.108 & .269 & .122 & .342 & .281 \\
\hline Concentrate on the youth segment & .033 & .107 & -.118 & .230 & .010 & .133 & .128 & -.100 & .830 & -.032 & .107 \\
\hline Airtel Live & .175 & .117 & .091 & .488 & .561 & -.264 & .038 & .073 & -.071 & .035 & .201 \\
\hline Mobile offices & .062 & -.062 & .105 & .019 & .092 & .142 & .028 & .043 & .095 & .885 & .107 \\
\hline Innovative SMS pack schemes & -.066 & .073 & .380 & .162 & .090 & .355 & .337 & -.260 & -.246 & .465 & -.077 \\
\hline Network connectivity & .047 & .033 & .211 & .628 & .191 & -.055 & .312 & -.159 & .325 & .199 & .166 \\
\hline Voice clearance & .315 & .012 & -.034 & .744 & -.042 & .174 & .042 & .200 & .127 & .143 & -.326 \\
\hline $\begin{array}{l}\text { Ease of availability and recharge } \\
\text { facility }\end{array}$ & -.066 & -.041 & -.029 & .188 & .099 & .213 & .823 & -.007 & .129 & .005 & .193 \\
\hline Network coverage & .094 & .357 & .047 & .696 & .076 & .103 & .238 & -.102 & -.136 & -.217 & .322 \\
\hline Roaming facility & -.109 & .031 & .091 & .055 & -.192 & .826 & .117 & .055 & -.004 & .324 & .024 \\
\hline Service quality & .096 & .440 & .447 & .372 & -.156 & .092 & .334 & .206 & .137 & -.352 & .015 \\
\hline Proactive and innovative service & .246 & .059 & .078 & .023 & .077 & .878 & .098 & .108 & .134 & -.059 & .052 \\
\hline Advertisemnt by celebrities & .829 & -.066 & .204 & .276 & .188 & .109 & .046 & -.157 & -.138 & .035 & .041 \\
\hline A R Rahman Ringtone & .879 & .199 & -.105 & .128 & .255 & .099 & .047 & .013 & -.066 & -.056 & -.021 \\
\hline Creative advertising campaigns & .762 & .201 & .152 & -.029 & .273 & -.055 & -.166 & -.034 & .186 & .044 & -.167 \\
\hline Word of Mouth Publicity & .402 & .265 & .015 & -.040 & -.102 & .208 & .496 & .186 & -.177 & .062 & -.420 \\
\hline
\end{tabular}




\begin{tabular}{|c|c|c|c|c|c|c|c|c|c|c|c|}
\hline $\begin{array}{c}\text { Various innovative schemes and } \\
\text { offers }\end{array}$ & .200 & -.001 & .508 & -.152 & .303 & .335 & -.006 & -.160 & .416 & .069 & .270 \\
\hline $\begin{array}{c}\text { Consideration on rebates and } \\
\text { discount on calls }\end{array}$ & .049 & .568 & -.075 & .149 & .126 & -.110 & .713 & -.039 & .103 & .060 & .101 \\
\hline Call tariff plans & -.080 & .218 & .144 & .064 & .031 & .068 & .298 & -.077 & .148 & .118 & .772 \\
\hline Newly introduced special 5 Plan & .246 & .028 & .271 & .108 & .192 & .314 & -.088 & .385 & -.273 & .194 & .485 \\
\hline Transparency in Billing & .337 & .174 & .154 & .068 & .774 & .175 & .027 & -.085 & -.057 & .079 & .112 \\
\hline Dealer services & .028 & .113 & .847 & .066 & .202 & -.057 & -.079 & -.150 & -.189 & -.061 & .014 \\
\hline Customer care services & .133 & .069 & .869 & .060 & -.065 & .175 & .006 & .089 & .007 & .245 & .128 \\
\hline
\end{tabular}

Extraction Method: Principal Component Analysis.

Rotation Method: Varimax with Kaiser Normalization.

Rotation converged in 20 iterations.

Table 7. Customers response towards marketing strategies factor

\begin{tabular}{|c|c|c|c|c|c|c|c|}
\hline \multicolumn{4}{|c|}{ Factor 1 : Branding strategy } & & & & \\
\hline \multicolumn{4}{|c|}{ Brand Image } & \multicolumn{4}{|c|}{ Indian Brand } \\
\hline & & Frequency & Percent & & & Frequency & Percent \\
\hline \multirow[t]{4}{*}{ Valid } & $\begin{array}{l}\text { strongly } \\
\text { agree }\end{array}$ & 296 & 74.0 & \multirow[t]{4}{*}{ Valid } & $\begin{array}{c}\text { strongly } \\
\text { agree }\end{array}$ & 200 & 50.0 \\
\hline & agree & 88 & 22.0 & & agree & 136 & 34.0 \\
\hline & neutral & 16 & 4.0 & & neutral & 64 & 16.0 \\
\hline & Total & 400 & 100.0 & & Total & 400 & 100.0 \\
\hline \multicolumn{4}{|c|}{ Market leader } & \multicolumn{4}{|c|}{ Reliable brand } \\
\hline & & Frequency & Percent & & & Frequency & Percent \\
\hline \multirow[t]{4}{*}{ Valid } & $\begin{array}{l}\text { strongly } \\
\text { agree }\end{array}$ & 232 & 58.0 & \multirow[t]{4}{*}{ Valid } & $\begin{array}{l}\text { strongly } \\
\text { agree }\end{array}$ & 216 & 54.0 \\
\hline & agree & 144 & 36.0 & & agree & 152 & 38.0 \\
\hline & neutral & 24 & 6.0 & & neutral & 32 & 8.0 \\
\hline & Total & 400 & 100.0 & & Total & 400 & 100.0 \\
\hline \multicolumn{4}{|c|}{ Status Symbol } & & & & \\
\hline \multirow{6}{*}{ Valid } & & Frequency & Percent & & & & \\
\hline & $\begin{array}{l}\text { strongly } \\
\text { agree }\end{array}$ & 144 & 36.0 & & & & \\
\hline & agree & 216 & 54.0 & & & & \\
\hline & neutral & 32 & 8.0 & & & & \\
\hline & disagree & 8 & 2.0 & & & & \\
\hline & Total & 400 & 100.0 & & & & \\
\hline \multicolumn{7}{|c|}{ Factor 2 :Business Outsourcing strategy and social initiatives } & \\
\hline \multicolumn{4}{|c|}{ Outsourcing to Ericcson and Nokia for network } & \multicolumn{4}{|c|}{ Outsourcing IBM to IT } \\
\hline & & Frequency & $\begin{array}{c}\text { Percen } \\
\mathrm{t}\end{array}$ & & & Frequency & Percent \\
\hline \multirow[t]{4}{*}{ Valid } & $\begin{array}{l}\text { strongly } \\
\text { agree }\end{array}$ & 136 & 34.0 & \multirow[t]{4}{*}{ Valid } & $\begin{array}{c}\text { strongly } \\
\text { agree }\end{array}$ & 56 & 14.0 \\
\hline & agree & 128 & 32.0 & & agree & 184 & 46.0 \\
\hline & neutral & 136 & 34.0 & & neutral & 160 & 40.0 \\
\hline & Total & 400 & 100.0 & & Total & 400 & 100.0 \\
\hline \multicolumn{4}{|c|}{ Social initiatives by the Company } & & & & \\
\hline & & Frequency & Percent & & & & \\
\hline
\end{tabular}




\begin{tabular}{|c|c|c|c|c|c|c|c|}
\hline \multirow[t]{5}{*}{ Valid } & $\begin{array}{l}\text { strongly } \\
\text { agree }\end{array}$ & 56 & 14.0 & & & & \\
\hline & agree & 184 & 46.0 & & & & \\
\hline & neutral & 136 & 34.0 & & & & \\
\hline & disagree & 24 & 6.0 & & & & \\
\hline & Total & 400 & 100.0 & & & & \\
\hline \multicolumn{8}{|c|}{ Factor 3: Target marketing } \\
\hline \multicolumn{4}{|c|}{ First Mover Advantage } & \multicolumn{4}{|c|}{ Concentrate on elite, professional ,entrepreneurs } \\
\hline & & Frequency & Percent & & & Frequenc & Percent \\
\hline \multirow[t]{5}{*}{ Valid } & $\begin{array}{l}\text { strongly } \\
\text { agree }\end{array}$ & 120 & 30.0 & \multirow[t]{5}{*}{ Valid } & $\begin{array}{c}\text { strongly } \\
\text { agree }\end{array}$ & 48 & 12.0 \\
\hline & agree & 160 & 40.0 & & agree & 232 & 58.0 \\
\hline & neutral & 96 & 24.0 & & neutral & 80 & 20.0 \\
\hline & disagree & 24 & 6.0 & & disagree & 40 & 10.0 \\
\hline & Total & 400 & 100.0 & & Total & 400 & 100.0 \\
\hline \multicolumn{4}{|c|}{ Concentrate on the youth segment } & & & & \\
\hline & & Frequency & Percent & & & & \\
\hline \multirow[t]{5}{*}{ Valid } & $\begin{array}{l}\text { strongly } \\
\text { agree }\end{array}$ & 144 & 36.0 & & & & \\
\hline & agree & 160 & 40.0 & & & & \\
\hline & neutral & 88 & 22.0 & & & & \\
\hline & disagree & 8 & 2.0 & & & & \\
\hline & Total & 400 & 100.0 & & & & \\
\hline \multicolumn{8}{|c|}{ Factor 4 : VAS Strategy } \\
\hline \multicolumn{4}{|c|}{ Airtel Live } & \multicolumn{4}{|c|}{ Mobile offices } \\
\hline & & Frequency & Percent & & & Frequency & Percent \\
\hline \multirow[t]{6}{*}{ Valid } & $\begin{array}{l}\text { strongly } \\
\text { agree }\end{array}$ & 160 & 40.0 & \multirow[t]{6}{*}{ Valid } & $\begin{array}{l}\text { strongly } \\
\text { agree }\end{array}$ & 160 & 40.0 \\
\hline & agree & 144 & 36.0 & & agree & 128 & 32.0 \\
\hline & neutral & 80 & 20.0 & & neutral & 64 & 16.0 \\
\hline & disagree & 16 & 4.0 & & disagree & 32 & 8.0 \\
\hline & Total & 400 & 100.0 & & $\begin{array}{l}\text { strongly } \\
\text { disagree }\end{array}$ & 16 & 4.0 \\
\hline & & & & & Total & 400 & 100.0 \\
\hline \multicolumn{4}{|c|}{ Innovative SMS pack schemes } & & & & \\
\hline & & Frequency & Percent & & & & \\
\hline \multirow[t]{6}{*}{ Valid } & $\begin{array}{l}\text { strongly } \\
\text { agree }\end{array}$ & 104 & 26.0 & & & & \\
\hline & agree & 128 & 32.0 & & & & \\
\hline & neutral & 72 & 18.0 & & & & \\
\hline & disagree & 72 & 18.0 & & & & \\
\hline & $\begin{array}{l}\text { strongly } \\
\text { disagree }\end{array}$ & 24 & 6.0 & & & & \\
\hline & Total & 400 & 100.0 & & & & \\
\hline \multicolumn{4}{|c|}{ FACTOR 5 : Networking/place strategy } & & & & \\
\hline \multicolumn{4}{|c|}{ Network connectivity } & \multicolumn{4}{|c|}{ Voice clearance } \\
\hline & & Frequency & Percent & & & Frequency & Percent \\
\hline Valid & $\begin{array}{l}\text { strongly } \\
\text { agree }\end{array}$ & 224 & 56.0 & Valid & $\begin{array}{c}\text { strongly } \\
\text { agree }\end{array}$ & 208 & 52.0 \\
\hline
\end{tabular}




\begin{tabular}{|c|c|c|c|c|c|c|c|}
\hline & agree & 120 & 30.0 & & agree & 152 & 38.0 \\
\hline & neutral & 24 & 6.0 & & neutral & 8 & 2.0 \\
\hline & disagree & 32 & 8.0 & & disagree & 32 & 8.0 \\
\hline & Total & 400 & 100.0 & & Total & 400 & 100.0 \\
\hline \multicolumn{4}{|c|}{ Ease of availability and recharge facility } & \multicolumn{4}{|c|}{ Network coverage } \\
\hline & & Frequency & Percent & & & Frequency & Percent \\
\hline \multirow[t]{5}{*}{ Valid } & $\begin{array}{c}\text { strongly } \\
\text { agree }\end{array}$ & 240 & 60.0 & \multirow[t]{5}{*}{ Valid } & $\begin{array}{c}\text { strongly } \\
\text { agree }\end{array}$ & 256 & 64.0 \\
\hline & agree & 144 & 36.0 & & agree & 104 & 26.0 \\
\hline & neutral & 16 & 4.0 & & neutral & 32 & 8.0 \\
\hline & Total & 400 & 100.0 & & disagree & 8 & 2.0 \\
\hline & & & & & Total & 400 & 100.0 \\
\hline \multicolumn{4}{|c|}{ Roaming facility } & \multicolumn{4}{|c|}{ Service quality } \\
\hline & & Frequency & Percent & & & Frequency & Percent \\
\hline \multirow[t]{6}{*}{ Valid } & $\begin{array}{c}\text { strongly } \\
\text { agree }\end{array}$ & 200 & 50.0 & \multirow[t]{6}{*}{ Valid } & $\begin{array}{c}\text { strongly } \\
\text { agree }\end{array}$ & 208 & 52.0 \\
\hline & agree & 128 & 32.0 & & agree & 144 & 36.0 \\
\hline & neutral & 32 & 8.0 & & neutral & 16 & 4.0 \\
\hline & disagree & 24 & 6.0 & & disagree & 24 & 6.0 \\
\hline & $\begin{array}{l}\text { strongly } \\
\text { disagree }\end{array}$ & 16 & 4.0 & & $\begin{array}{l}\text { strongly } \\
\text { disagree }\end{array}$ & 8 & 2.0 \\
\hline & Total & 400 & 100.0 & & Total & 400 & 100.0 \\
\hline \multicolumn{4}{|c|}{ Proactive and innovative service } & & & & \\
\hline & & Frequency & Percent & & & & \\
\hline \multirow[t]{5}{*}{ Valid } & $\begin{array}{c}\text { strongly } \\
\text { agree }\end{array}$ & 136 & 34.0 & & & & \\
\hline & agree & 152 & 38.0 & & & & \\
\hline & neutral & 96 & 24.0 & & & & \\
\hline & disagree & 16 & 4.0 & & & & \\
\hline & Total & 400 & 100.0 & & & & \\
\hline \multicolumn{8}{|c|}{ Factor 6 :Promotion strategy } \\
\hline \multicolumn{4}{|c|}{ Advertisemnt by celebrities } & \multicolumn{4}{|c|}{ A R Rahman Ringtone } \\
\hline & & Frequency & Percent & & & Frequency & Percent \\
\hline \multirow[t]{5}{*}{ Valid } & $\begin{array}{l}\text { strongly } \\
\text { agree }\end{array}$ & 160 & 40.0 & \multirow[t]{5}{*}{ Valid } & $\begin{array}{c}\text { strongly } \\
\text { agree }\end{array}$ & 176 & 44.0 \\
\hline & agree & 112 & 28.0 & & agree & 112 & 28.0 \\
\hline & neutral & 64 & 16.0 & & neutral & 64 & 16.0 \\
\hline & disagree & 64 & 16.0 & & disagree & 48 & 12.0 \\
\hline & Total & 400 & 100.0 & & Total & 400 & 100.0 \\
\hline \multicolumn{4}{|c|}{ Creative advertising campaigns } & \multicolumn{4}{|c|}{ Word of Mouth Publicity } \\
\hline \multirow{6}{*}{ Valid } & & Frequency & Percent & & & Frequency & Percent \\
\hline & $\begin{array}{l}\text { strongly } \\
\text { agree }\end{array}$ & 160 & 40.0 & \multirow[t]{5}{*}{ Valid } & $\begin{array}{c}\text { strongly } \\
\text { agree }\end{array}$ & 104 & 26.0 \\
\hline & agree & 160 & 40.0 & & agree & 160 & 40.0 \\
\hline & neutral & 64 & 16.0 & & neutral & 80 & 20.0 \\
\hline & disagree & 16 & 4.0 & & disagree & 56 & 14.0 \\
\hline & Total & 400 & 100.0 & & Total & 400 & 100.0 \\
\hline \multicolumn{4}{|c|}{ Factor 7 : Pricing Strategy } & & & & \\
\hline \multicolumn{4}{|c|}{ Various innovative schemes and offers } & Cons & ration on reb & es and discoun & calls \\
\hline
\end{tabular}




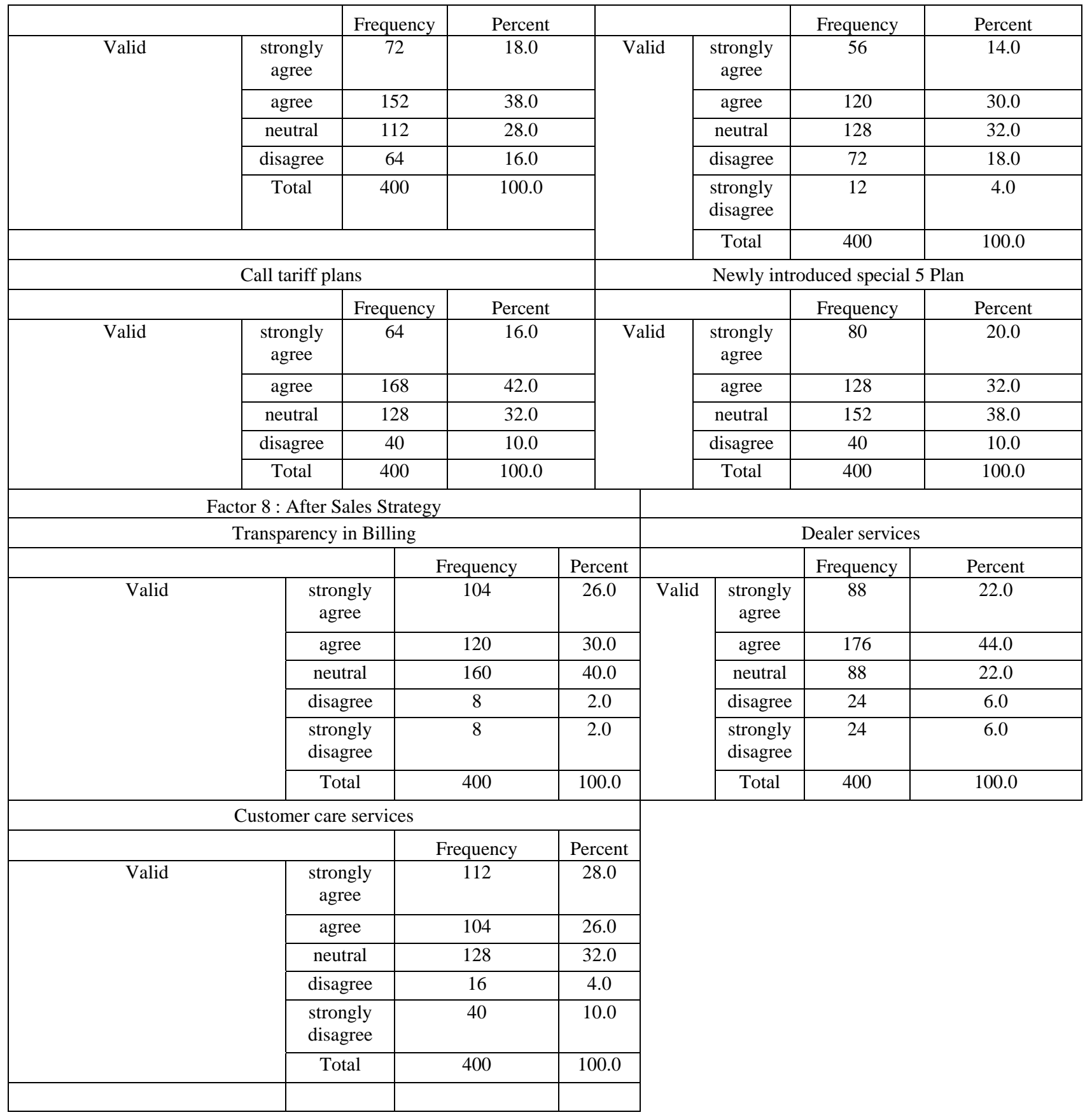




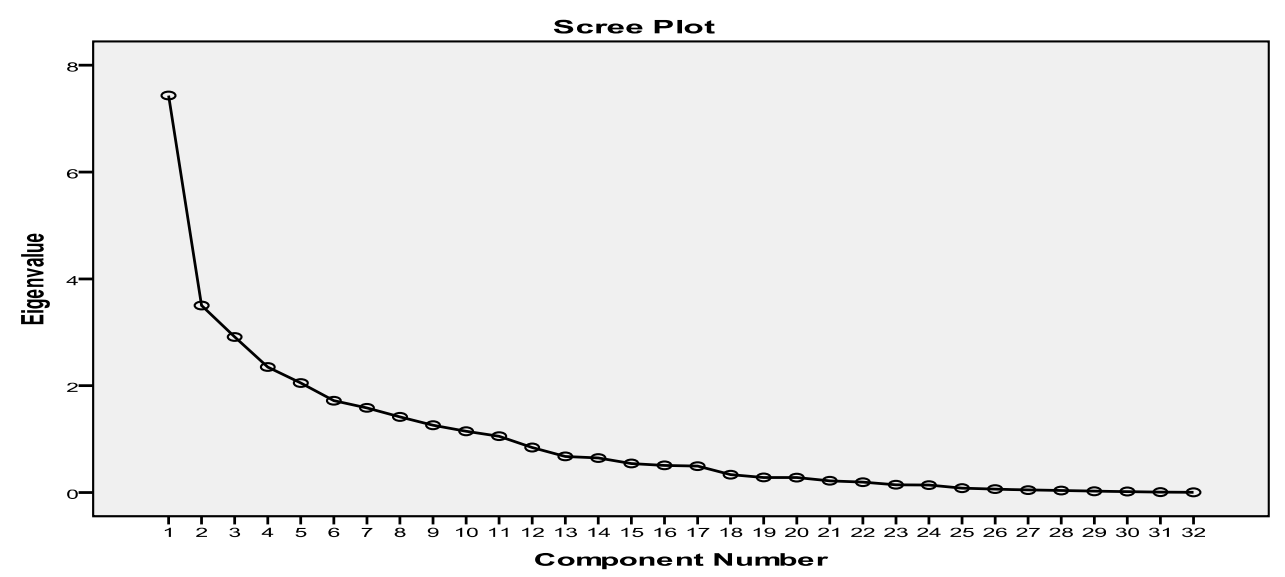

Figure 1. Screen Plot from Factor Analysis 